\title{
Serological tests in the differentiation of staphylococcal and tuberculous bone disease
}

\author{
A. G. TAYLOR, JOSEPHINE COOK, W. J. FINCHAM, AND F. J. C. MILLARD \\ From the Department of Clinical Pathology, The Institute of Orthopaedics (University of London), \\ Royal National Orthopaedic Hospital, Stanmore, Middlesex, and the Department of Thoracic Medicine, \\ St James' Hospital, Balham, London
}

SYNOPSIS The haemagglutination test for antileucocidin is frequently positive in cases of bone tuberculosis in the absence of obvious staphylococcal infection. This test is therefore of little practical use in the differentiation of staphylococcal and tuberculous bone disease, and its use has been discontinued at the Royal National Orthopaedic Hospital.

The antigamma haemolysin test in bone tuberculosis appears to give rise to few false positive results. Our observations confirm that the anti-alpha haemolysin and antigamma haemolysin tests used together reveal about $80 \%$ of cases of staphylococcal bone infection on first presentation or relapse.

The measurement of serum antistaphylococcal alpha haemolysin levels is widely used as a test for deep-seated staphylococcal infection, especially in orthopaedic cases. However, it is well recognized that a raised anti-alpha haemolysin titre is found only in about two-thirds of patients who have staphylococcal bone infections (Queneau, Lejeune, Bertoye, Bouvier, Bertrand, and Perrier, 1972). At the Royal National Orthopaedic Hospital during the past 12 years a second staphylococcal antibody, antileucocidin, has also been quantitated as recommended by Towers and Gladstone (1958) and Lack and Towers (1962), using an indirect haemagglutination technique (Towers, 1961). Although lacking specificity this is the only simple method available for the measurement of antileucocidin levels suitable for routine use.

In this paper the value of the antileucocidin test has been assessed in differentiating staphylococcal and tuberculous bone infection and has been found to give a high percentage of false positive results in tuberculosis. The more recently described antistaphylococcal gamma haemolysin test (Taylor and Plommet, 1973) has been further investigated and our results indicate that it is more specific.

\section{Materials and Methods}

SELECTION OF CASES

Only those cases in which the causative organism Received for publication 10 December 1974. was isolated have been included in the study. Staphylococcal antibody levels were estimated on serum samples obtained at the time the patient was first examined. Patients who had already received antibiotic therapy for more than seven days at this time were excluded from the study.

ESTIMATION OF STAPHYLOCOCCAL

ANTIBODY LEVELS

Anti-alpha haemolysin and antileucocidin levels were estimated using the methods described by Lack and Towers (1962). Levels of anti-alpha haemolysin of not more than 2 International units (Iu) per $\mathrm{ml}$ of serum were regarded as normal, levels of more than 2 but less than 4 Iu per $\mathrm{ml}$ as intermediate, and 4 or more Iu per $\mathrm{ml}$ as raised. In the anti-leucocidin test a titre of 0 to 2 units per $\mathrm{ml}$ was considered normal, 4 to 8 units per $\mathrm{ml}$ as intermediate, and 16 or more units per $\mathrm{ml}$ as raised.

Antigamma haemolysin was estimated as described by Taylor and Plommet (1973). In this method 5 units of gamma haemolysin is added in a volume of $0.2 \mathrm{ml}$ to $1 \mathrm{ml}$ of serum dilution in phosphate-buffered saline at $\mathrm{pH}$ 6.8. After mixing and standing at room temperature for 10 minutes $0.2 \mathrm{ml}$ of a $12 \%$ suspension of washed human group $O$ red cells is added and mixed. The tubes are then incubated at $37^{\circ} \mathrm{C}$ for 20 minutes and then centrifuged. The endpoint is the last tube showing no haemolysis. Positive and negative control sera are routinely included in the test. 
In this test a level of up to 2 units per ml of antigamma haemolysin was considered normal, 4 units per $\mathrm{ml}$ as intermediate, and 8 units per $\mathrm{ml}$ or higher as raised.

\section{BACTERIOLOGICAL METHODS}

Cultures of material from lesions were made on blood agar and MacConkey plates; pyogenic organisms were identified by standard methods. In possible cases of tuberculosis smears were stained by Ziehl-Neelsen's method, or were examined microscopically under ultraviolet light using an auraminerhodamine stain. Material was also inoculated onto Löwenstein's medium and subcutaneously into guinea-pigs which were killed two months later and examined for evidence of tuberculous disease.

\section{Results}

\section{ANTILEUCOCIDIN AND ANTI-ALPHA}

HAEMOLYSIN LEVELS IN BONE TUBERCULOSIS A total of 37 cases of bone tuberculosis with no evidence of staphylococcal infection has been studied and the results are shown in table I. The average age of the patients was 36 years, ranging from 7 to 68 years. In this series 10 patients $(27 \%)$ showed raised antileucocidin levels. Five of these had a level of 16 units per $\mathrm{ml}$ of serum, two of 32 units, one of 64 units, and two of 256 units per $\mathrm{ml}$. In the anti-alpha haemolysin test four $(11 \%)$ showed raised antibody levels; three of these were in the range 4-5 Iu per $\mathrm{ml}$ and one showed a level of 5 to $8 \mathrm{Iu}$ per $\mathrm{ml}$.

\section{ANTI-ALPHA AND ANTIGAMMA HAEMOLYSIN}

LEVELS IN TUBERCULOSIS

A further series of 28 patients with bone and pulmonary tuberculosis was studied. The results are shown in table II. The average age of the patients was 43 , ranging from 15 to 68 years. (The sera from the 37 patients with bone tuberculosis, which had been used for the anti-alpha and antileucocidin estimations reported above, had been discarded before the introduction of the antigamma haemolysin test.)

Anti-alpha haemolysin levels in this series were all normal, except in three patients, two of whom showed definitely raised levels (4-5 Iu per $\mathrm{ml}$ ). These were both in the bone group. One patient in the pulmonary group showed an intermediate level of 2-4 Iu per $\mathrm{ml}$ ).

The antigamma haemolysin levels were raised in four patients, all of whom had levels of 8 units per $\mathrm{ml}$. Two of the four had bone tuberculosis and two had pulmonary tuberculosis. Two patients showed intermediate levels, both in the bone group. The remaining 22 patients all showed normal levels.

Of the four patients showing antigamma levels of 8 units per $\mathrm{ml}$, two had raised anti-alpha levels (4-5 Iu per $\mathrm{ml}$ ) and one was in the intermediate range (2-4 $\mathrm{Iu}$ per $\mathrm{ml}$ ). The fourth had a normal level. The two patients showing intermediate levels in the antigamma haemolysin test both had normal anti-alpha haemolysin levels. Therefore out of 28 cases of tuberculosis, with no evidence of concurrent staphylococcal infection, there were four false positives in the antigamma haemolysin test, and two of these were also positive in the anti-alpha haemolysin test.

ANTILEUCOCIDIN, ANTI-ALPHA HAEMOLYSIN, AND ANTIGAMMA HAEMOLYSIN IN STAPHYLOCOCCAL OSTEOMYELITIS

In a series of 16 patients with staphylococcal osteomyelitis with an average age of 36 (range 6 to

\begin{tabular}{|c|c|c|c|c|c|c|}
\hline & \multicolumn{3}{|c|}{ Anti-alpha Haemolysin $(\mathrm{I} u / \mathrm{ml})$} & \multicolumn{3}{|c|}{ Antileucocidin (units/ml) } \\
\hline & $\begin{array}{l}\text { Normal } \\
0-2\end{array}$ & $\begin{array}{l}\text { Intermediate } \\
2-4\end{array}$ & $\begin{array}{l}\text { Raised } \\
4 \text { or more }\end{array}$ & $\begin{array}{l}\text { Normal } \\
0-2\end{array}$ & $\begin{array}{l}\text { Intermediate } \\
4-8\end{array}$ & $\begin{array}{l}\text { Raised } \\
16 \text { or more }\end{array}$ \\
\hline Number of patients & 29 & 4 & 4 & 13 & 14 & 10 \\
\hline
\end{tabular}

Table I Anti-alpha haemolysin and antileucocidin in 37 cases of bone tuberculosis

\begin{tabular}{|c|c|c|c|c|c|c|}
\hline & \multicolumn{3}{|c|}{ Anti-alpha Haemolysin $(\mathrm{Iu} / \mathrm{ml})$} & \multicolumn{3}{|c|}{ Antigamma Haemolysin (units $/ m l$ ) } \\
\hline & $\begin{array}{l}\text { Normal } \\
0-2\end{array}$ & $\begin{array}{l}\text { Intermediate } \\
2-4\end{array}$ & $\begin{array}{l}\text { Raised } \\
4 \text { or more }\end{array}$ & $\begin{array}{l}\text { Normal } \\
0-2\end{array}$ & $\begin{array}{l}\text { Intermediate } \\
4\end{array}$ & $\begin{array}{l}\text { Raised } \\
8 \text { or more }\end{array}$ \\
\hline $\begin{array}{l}\text { Bone Tuberculosis } \\
\text { Number of patients }\end{array}$ & 9 & 0 & 2 & 7 & 2 & 2 \\
\hline $\begin{array}{l}\text { Pulmonary Tuberculosis } \\
\text { Number of patients }\end{array}$ & 16 & 1 & 0 & 15 & 0 & 2 \\
\hline
\end{tabular}

Table II Anti-alpha and antigamma haemolysins in 28 cases of tuberculosis 


\begin{tabular}{|c|c|c|c|c|c|c|c|c|c|}
\hline & \multicolumn{3}{|c|}{ Anti-alpha Haemolysin $(\mathrm{Iu} / \mathrm{ml})$} & \multicolumn{3}{|c|}{ Antileucocidin (units $/ m l)^{1}$} & \multicolumn{3}{|c|}{ Antigamma Haemolysin (units/ml) } \\
\hline & $\begin{array}{l}\text { Normal } \\
0-2\end{array}$ & $\begin{array}{l}\text { Intermediate } \\
2-4\end{array}$ & $\begin{array}{l}\text { Raised } \\
4 \text { or more }\end{array}$ & $\begin{array}{l}\text { Normal } \\
0-2\end{array}$ & $\begin{array}{l}\text { Intermediate } \\
4-8\end{array}$ & $\begin{array}{l}\text { Raised } \\
16 \text { or more }\end{array}$ & $\begin{array}{l}\text { Normal } \\
0-2\end{array}$ & $\begin{array}{l}\text { Intermediate } \\
4\end{array}$ & $\begin{array}{l}\text { Raised } \\
8 \text { or more }\end{array}$ \\
\hline Number of patients & 2 & 3 & 11 & 3 & 8 & 4 & 4 & 3 & 9 \\
\hline
\end{tabular}

Table III Anti-alpha haemolysin, antileucocidin, and antigamma haemolysin in 16 cases of staphylococcal infection of bone

${ }^{1}$ Not estimated in one case.

64 years), we have obtained the following results (table III). Antileucocidin was measured in only 15 of these. Four showed raised levels, eight were in the intermediate range, and three were normal.

In the anti-alpha haemolysin test, 11 patients had raised levels, three were in the intermediate range, and two were normal.

In the antigamma haemolysin test nine had raised levels, three were in the intermediate range, and four were normal.

If the results of the anti-alpha and antigamma haemolysin tests are taken in conjunction, the findings are as follows. The two patients found to be seronegative in the anti-alpha haemolysin test showed raised antigamma haemolysin levels. Of the three patients with intermediate levels in the antialpha haemolysin test, one showed a raised level in the antigamma haemolysin test and the other two were intermediate. Thus in the five patients where seronegative or equivocal results were obtained in the anti-alpha haemolysin test, the antigamma haemolysin test permitted a positive diagnosis of deep-seated staphylococcal infection to be made in three instances.

If the results in the seven patients with staphylococcal osteomyelitis not seropositive in the antigamma haemolysin test are examined more closely, the situation is as follows. Four showed normal antigamma haemolysin levels, but these all had raised anti-alpha haemolysin levels. Three showed intermediate levels, and two of these also had intermediate levels of anti-alpha haemolysin; the third showed a definitely raised anti-alpha haemolysin titre. So that out of the seven patients who were seronegative or equivocal in the antigamma haemolysin test, a positive diagnosis of staphylococcal infection could be made in five instances; the other two patients showed equivocal levels in both tests.

\section{Discussion}

It would be of immense value if in infective bone lesions the specificity of the host's immunological response to the invading organism would allow identification of the pathogen by serological tech- niques. Such an approach would be advantageous where surgical intervention is not indicated. Positive serology would assist the clinician in deciding what antibiotic therapy to prescribe in circumstances where the organism cannot be isolated. Our experience has led us to believe that the serological tests for staphylococcal antibodies, commonly in use at the present time, are inadequate. In the differential diagnosis of tuberculous and staphylococcal bone infection two problems exist. First, in staphylococcal infection the antibody response will not necessarily involve the production of neutralizing antibodies to one specific antigen such as alpha haemolysin. Therefore any one test cannot be expected to reveal more than a proportion of cases in which the staphylococcus is the causative organism. Secondly, in non-staphylococcal infection the ubiquity of the staphylococcus may sometimes be responsible for raised antistaphylococcal antibody levels in the absence of deep-seated infection (Packalen and Bergqvist, 1947).

The first of these problems was recognized by Towers and Gladstone (1958) who proposed the estimation of antileucocidin titres as well as antialpha haemolysin levels in the diagnosis of deepseated staphylococcal infection.

The quantitation of antileucocidin levels was originally dependent upon the ability of this antibody to neutralize leucocidin and thus inhibit its toxicity for human polymorphonuclear leucocytes (Gladstone and van Heyningen, 1957). This bioscopic technique was laborious and prompted the development of a technically simpler haemagglutination method in which a partially purified preparation of leucocidin was used to sensitize tanned sheep red cells (Towers, 1961). This was then used in the assay of antileucocidin levels in the large series of subjects studied by Lack and Towers (1962) and has since been in routine use at the Royal National Orthopaedic Hospital. The advantage of the original bioscopic technique was its high specificity related to the neutralization of the toxin by its specific antibody, and our present results, which show a high proportion of false positives in tuberculosis, can be attributed to the use of the non-specific haemag- 
glutination method. Red cells sensitized with highly purified leucocidin were not agglutinated by antisera (W. J. Fincham, unpublished results) and it has not, therefore, been possible to increase the specificity of this indirect method. We suggest that several antigens in the crude leucocidin preparation are involved in the haemagglutination reaction, but that neither of the two proteins which comprise the toxin known as leucocidin is the major agglutinating antigen. The haemagglutination titre probably reflects therefore a summation of a number of antigen-antibody reactions. The very high 'antileucocidin' titres we have seen in tuberculous bone disease may well be related to the host's previous experience of the staphylococcus. In the tuberculous patient a significant anamnestic antibody response could be elicited, in the absence of deep-seated staphylococcal infection, due to the adjuvant properties of the tubercle bacillus. The rise in antibody levels to one specific antigen such as alpha haemolysin may, in the large majority of cases of tuberculosis, not be great enough to exceed the normal range. The haemagglutination technique for the estimation of antileucocidin titres, however, due to its non-specific nature, can also measure other staphylococcal antibody levels and therefore give rise to false positive results.

Our results in this paper not only suggest that the specificity of the antileucocidin test is poor, but also that it may reveal only a small proportion of cases of staphylococcal osteomyelitis when used as an initial diagnostic test. Lack and Towers reported a higher proportion of positive results, but they studied the serology over a period of several months in each case. We conclude that the indirect method for the estimation of antileucocidin levels is unsatisfactory for use in conjunction with the anti-alpha haemolysin test in the differentiation of staphylococcal and tuberculous bone infection and the test has been discontinued at the Royal National Orthopaedic Hospital.

The results in this paper, together with those already published (Taylor and Plommet, 1973), suggest that the use of both the anti-alpha haemolysin and antigamma haemolysin tests will provide positive serology in about $80 \%$ of patients with untreated or recurrent staphylococcal osteomyelitis at the time of first presentation or relapse.

Previous workers have speculated on the factors which could be responsible for the seronegativity to alpha toxin seen in cases of proven staphylococcal infection. Rogers $(1954,1956)$ suggested that macroanions, such as chondroitin sulphate, hyaluronic acid, and nucleic acids, interfere with the production of alpha toxin by the staphylococcus, and Bergman (1957) reported that sodium nucleate inhibited its formation. A further possibility is that alpha toxin may form complexes with other molecules, under which conditions it may not give rise to neutralizing antibodies. Recently Kaplan and Wannamaker (1974) showed that lipids extracted from rabbit skin not only inhibit the haemolytic action of streptolysin $O$, but also suppress the immune response to this streptococcal antigen. Alpha toxin is not inhibited by lipids, but it is possible that it may form complexes with other molecules resulting in an altered antigenicity. The antigamma haemolysin test resembles the anti-alpha haemolysin test in general principles. Where gammalysin is used as an antigen, however, lipids might well be responsible for an immunosuppressive effect, as, like streptolysin $\mathrm{O}$, this toxin is inhibited by cholesterol and phospholipids (Taylor and Bernheimer, 1974). The effect of serum lipids on gamma haemolysin has not yet been studied in detail and our results to date suggest that its nonspecific inhibition by serum from patients with tuberculosis is not common. However, the possibility of such inhibition should be borne in mind, as Gallin, Kaye, and O'Leary (1969) found alterations in serum lipids in a number of infections by Gram-negative organisms, and Thoen, Karlson, and Ellefson (1972) have shown that changes in serum lipids occur in rabbits infected with $M$. bovis and M. avium.

We wish to acknowledge the cooperation of the surgeons of the Royal National Orthopaedic Hospital whose patients have been studied in this investigation. We are grateful to Dr P. Queneau for samples of serum from some patients with bone tuberculosis. Thanks are due to $\mathrm{Mr} \mathrm{W}$. H. Bradley who performed the anti-alpha haemolysin and antileucocidin tests. Gamma haemolysin was made available through facilities provided by $\mathrm{Dr} M$. Plommet, Institut National de la Recherche Agronomique, Nouzilly, 37-France, and the expertise of Monsieur G. Bézard is gratefully acknowledged.

The work was supported in part by the Sir William Coxen Trust Fund.

\section{References}

Bergman, S. (1957). Inhibiting effect of sodium nucleate on the production of alpha-hemolysin by certain staphylococci. Acta path. microbiol. scand., 41, 537-541.

Gallin, J. I., Kaye, D., and O'Leary, W. M. (1969). Serum lipids in infection. New Engl. J. Med., 281, 1081-1086.

Gladstone, G. P., and van Heyningen, W. E. (1957). Staphylococcal leucocidins. Brit. J. exp. Path., 38, 123-137.

Kaplan, E. L., and Wannamaker, L. W. (1974). Streptolysin O: suppression of its antigenicity by lipids extracted from skin. Proc. Soc. exp. Biol. (N.Y.), 146, 205-208.

Lack, C. H., and Towers, A. G. (1962). Serological tests for staphylococcal infection. Brit. med. J., 2, 1227-1231.

Packalen, T., and Bergqvist, S. (1947). Staphylococci in throat and nose and antistaphylolysin titre. Acta med. scand., 127, 291-312. 
Queneau, P., Lejeune, E., Bertoye, A., Bouvier, M., Bertrand, J., and Perrier, J. (1972). Intérêt du dosage des antistaphylolysines en pathologie ostéo-articulaire. Lyon méd., 228, 345-350.

Rogers, H. J. (1954). The rate of formation of hyaluronidase, coagulase and total extracellular protein by strains of Staphylococcus aureus. J. gen. Microbiol., 10, 209-220.

Rogers, H. J. (1956). The formation of extracellular enzymes by staphylococci. Ann. N.Y. Acad. Sci., 65, 132-138.

Taylor, A. G., and Bernheimer, A. W. (1974). Further characterization of staphylococcal gamma-hemolysin. Infect. and Immun., 10, 54-59.

Taylor, A. G., and Plommet, M. (1973). Anti-gamma haemolysin as a diagnostic test in staphylococcal osteomyelitis. J. clin. Path., 26. 409-412.

Thoen, C. O., Karlson, A. G., and Ellefson, R. D. (1972). Serum lipid-lipoprotein profiles in rabbits infected with Mycobacterium bovis, Listeria monocytogenes, Pasteurella pseudotuberculosis and with $M$ avium. Mayo Clin. Proc. 47, 258-269.

Towers, A. G. (1961). A haemagglutination test for anti-PantonValentine leucocidin in serum: an interim report on 200 cases. J. clin. Path., 14, 161-163.

Towers, A. G., and Gladstone, G. P. (1958). Two serological tests for staphylococcal infection. Lancet, 2, 1192-1195. 